\title{
Analysis of Marketing Function, Marketing Efficiency and Spatial Co- Integration of Rohu (Labeo Rohita) Fish in Some Selected Areas of Bangladesh
}

\author{
Umme Aymon Janifa ${ }^{1^{*}}$, Md. Imran Omar ${ }^{2}$, Sabur $\mathbf{S A}^{3}$, Moniruzzaman $\mathbf{M}^{3}$ and Haque Md.S \\ ${ }^{1}$ Department of Aquaculture, Faculty of Fisheries, Bangladesh Agricultural University, Mymensingh-2202, Bangladesh \\ ${ }^{2}$ Agricultural Economics Division, Bangladesh Agricultural Research Institute, Joydevpur, Gazipur-1701, Bangladesh \\ ${ }^{3}$ Department of Agribusiness and Marketing, Faculty of Agricultural Economics and Rural Sociology, Bangladesh Agricultural University, Mymensingh-2202, Bangladesh \\ ${ }^{4}$ Department of Agricultural Economics, Faculty of Agricultural Economics and Rural Sociology, Bangladesh Agricultural University, Mymensingh-2202, Bangladesh
}

\begin{abstract}
The study was undertaken to examine the value chain, value addition, marketing cost \& margin, marketing efficiency and market integration of rohu fish in selected areas of Bangladesh during the month of July-August 2013. The objectives of the study were to estimate costs and margins, seasonal price variation and to test market integration of rohu fish. Primary and secondary data were used for this study. The higher marketing cost was incurred by paiker and the lowest by retailer. On the other hand, retailers earned the highest net marketing margins. Chain II was found the most efficient chain. Analysis of market integration shows that rohu fish market in Bangladesh was well integrated. The findings of the study revealed that the marketing of rohu fish was a profitable business and some recommendations were provided for the improvement of rohu fish marketing in the country.
\end{abstract}

Keywords: Value addition; Marketing cost \& margin; Marketing efficiency; Spatial co-integration

\section{Introduction}

In the agro-based economy of Bangladesh, the fisheries sector contributes near about $58 \%$ of animal protein to the daily diets of the population, about $3.74 \%$ to GDP, $4.04 \%$ in export earnings and $20.87 \%$ to agriculture in 2010-11 [1]. This sector provide full-time employment of 1.4 million professional Fishers and Fish farmer, and 11 million part-time Fishers, fish farmer and women, which is about $10 \%$ of total population. The marketing system and structure is one of the main circumstances of socio economic condition of the local people and production system of any area. With intra-linkage and inter-linkage from production sector to consumer sector, it is a chain of various systems involved in marketing. As fish and fishery products are highly traded commodities, fish production is a necessary part of the marketing process to make a whole complete. The total fish production in Bangladesh was estimated to near about 2.56 million tons in 20092010, of which near about 2.07 (80.59\%) and 0.5 (19.41\%) million tons came from inland and marine waters respectively [1]. About $97 \%$ of the production is marketed internally for domestic consumption while the remaining 3\% exported to the foreign [2]. Rohu fish is the most important among the three Indian major carp species used in carp poly culture systems. This graceful Indo-Gangetic reverie species is the natural inhabitant of the riverine system of northern and central India, and the rivers of Pakistan, Bangladesh and Myanmar. In India, it has been transplanted into almost all reverie systems including the freshwaters of Andaman, where its population has successfully established. The species has also been introduced in many other countries, including Sri Lanka, the former USSR, Japan, China, Philippines, Malaysia, Nepal and some countries of Africa. Bangladesh is considered one of the most suitable countries in the world for freshwater aquaculture, because of its favorable agro-climatic conditions. A sub-tropical climate and vast areas of shallow water provide ideal conditions for fish production. Rohu fish farming is widespread in many Asian countries including China, Indonesia, Philippines, Thailand and Vietnam due to its rapid growth rate, high market demand and increasing consumer acceptance [3]. The present study aimed to identify, particularly the marketing chains, to analyze the market integration. The study would make recommendation and suggestions to improve the organization and operation of rohu fish marketing with a view to enhancing efficiency by analyzing the present marketing problems. In view of these, the survey was conducted to examine marketing and price behavior of rohu fish in selected areas of Mymensingh district. Thus the study was conducted for understanding the present situation of marketing system of rohu fish in different regions of Bangladesh with following objectives.

The specific objectives of the study are to:

1. analysis of marketing function rohu fish and the marketingintegration of rohu fish

\section{2. identify different marketing chains of rohu fish}

3. determine the extent of value addition in terms of costs in successive stages of rohu fish movement and

4. examine the marketing margins of the intermediaries of rohu fish.

\section{Materials and Methods}

The present study was conducted on the field survey method where the primary data were collected from the respondents. Secondary data was collected from journals, thesis and raw data from monthly bulletin of Directorate of Agricultural Marketing (DAM) and District Fisheries Office [4]. In Mymensingh district there were a number of successful rohu fish producers, trader's i.e.Aratdar, Bepari, Paiker and retailer etc. The study area is confined to two Upazilas namely Bhaluka Upazila and

*Corresponding author: Umme Aymon Janifa, Professor of Fisheries Bangladesh Agricultural University, Bangladesh, Tel: + 8801734128910; E-mail: E-mail: janifa2011co@gmail.com

Received July 29, 2014; Accepted September 06, 2014; Published September 30, 2014

Citation: Janifa UA, Omar Mdl, Sabur SA, Moniruzzaman M, Haque MdS (2014) Analysis of Marketing Function, Marketing Efficiency and Spatial Co-Integration of Rohu (Labeo Rohita) Fish in Some Selected Areas of Bangladesh. J Bus Fin Aff 3: 123 doi:10.4172/2167-0234.1000123

Copyright: $\odot 2014$ Janifa UA, et al. This is an open-access article distributed under the terms of the Creative Commons Attribution License, which permits unrestricted use, distribution, and reproduction in any medium, provided the original author and source are credited. 
Phulpur Upazila in Mymensingh district, where the cultivation of rohu fish was concentrated. Purposive sampling techniques were used for selecting the sample. Total sample size of the study was 100 . Selected samples consisted of 30 fish farmers and 70 traders. For this study, 30 stocking ponds were selected from Tarakanda and Baluka upazilas. The intermediaries dealing with rohu marketing were categorized into three groups, namely, Aratdar, Paiker and retailer. From different stages of fish marketing 25 Paikers, 10 Aratdars and 35 retailers were selected as respondents for the study. Among them two Aratdars, five Paiker and ten retailers from Tarakanda, three Aratdars, five Paiker and ten retailers from Trishal, and ten Paikers, five Aratdars and twenty retailers from Kawran Bazar of Dhaka city were selected. The data were collected intensively by using structured interview schedules. The weekly average wholesale prices of rohu of various markets like Dhaka, Chittagong, Khulna, Sherpur, Comilla, Bogra, Rangpur, Rajshahi, Mymensingh, Sylhet, Gazipur and Noakhali during 2000 to 2012 were collected from Department of Agricultural Marketing (DAM) [4]. Later it was converted into monthly figures.

\section{Analytical techniques}

Farmer's net prices, farmer's gross share, farmer's net share and Marketing efficiency were calculated by using following formulas:

5. Farmer's net price $=$ Farmer's sale price - Farmer's marketing cost

6. Percentages of total value addition cost/net profit =

$\frac{\text { Marketing cost / Net marketing margin }}{\text { Tota marekting cost / net marekting margin }} \times 100$

7. Farmer's net share $=\frac{\text { Farmer's net price }}{\text { Retail price }} \times 100$

8. Gross margin $=$ Sale Price - purchase Price .

9. Net margin $=$ gross margin - marketing costs

Marketing efficiency was calculated using Acharaya's formula [5]:

$\mathrm{ME}=\frac{\mathrm{FP}}{\mathrm{MC}+\mathrm{MM}}$

Where,

$\mathrm{ME}=$ Marketing efficiency

$\mathrm{FP}=$ Net price received by farmers

$\mathrm{MC}=$ Total marketing cost

$\mathrm{MM}=$ Total net marketing margin of intermediaries.

A higher value of ME denotes higher level of efficiency and vice versa.

\section{Market integration}

Market integration was measured by co-integration method.The bulk of econometric theories have been based on the assumption that the underlying data process is stationary. Stochastic process is said to be stationary if its mean and variance are constant over time and the value of co-variance between two time periods depends only on the distance or gap or lag between the two time periods and not the actual time at which the co-variance is [6]. In practice, most economic time series are non-stationary. An applying regression models to non-stationary data may arise the problem of "spurious or nonsense" correlation [6]. To overcome such problems, the concept of co-integration was used because it offers a means of identifying and hence avoiding the spurious. The underlying principle of co-integration analysis is that although trend of many economic series show upward or downwards over time in a non-stationary fashion, group of variables may drift together. Unit root and Co-integration test: The individual price series were tested for the order of integration to determine whether or not they are stationary which is known as the unit root test [6]. A number of tests for stationary are available in the literature; these include the DickeyFuller (DF) test, the Augmented Dickey-Fuller (ADF) test (Dickey and Fuller, 1981) and the Philips-Perron (PP) test.

For theoretical and practical reasons, the Dickey-Fuller test is applied to regressions run in the following forms:

$Y_{t}$ is a random walk or without constant:

$\Delta Y_{t}=\delta Y_{t-1}+e_{t}$

$Y_{t}$ is a random walk with drift or constant:

$\Delta Y_{t}=\beta_{1}+\delta Y_{t-1}+e_{t}$

$Y_{t}$ is a random walk with drift around a stochastic trend (constant plus trend):

$\Delta Y_{t}=\beta_{1}+\beta_{2} t+\delta Y_{t-1}+e_{t}$

Where $t$ is the time or trend variable.

In each case the null hypothesis is $\delta=0(\rho=1)$; that is, there is a unit root in the time series i.e. the series is non-stationary. The alternative hypothesis is that $\delta$ is less than zero; that is, the time series is stationary. Under the null hypothesis, the conventionally computed $\mathrm{t}$ statistics is known as the $\tau$ (tau) statistic, whose critical values have been tabulated by Dickey and Fuller. If the null hypothesis is rejected, it means that $Y_{t}$ is a stationary time series with zero mean in the case of (1), that $Y_{t}$ is stationary with a non-zero mean $\left[=\beta_{1} /(1-\rho)\right]$ in the case of (2), and that $Y_{t}$ is a stationary around a deterministic trend in equation (3).

It is extremely important to note that the critical values of the tau test to test the hypothesis that $\delta=0$, are different for each of the preceding three specifications of the DF test. If the computed absolute value of the tau statistics $(\tau)$ exceeds the DF or MacKinnon critical tau values, we reject the hypothesis that $\delta=0$, in which case the time series is stationary. On the other hand, if the computed $(\tau)$ does not exceed the critical tau value, we do not reject the null hypothesis, were the time series is non-stationary.

In conducting the DF test as in (1), (2), or (3), it was assumed that the error term $e_{t}$ was uncorrelated. But in case the $e_{t}$ are correlated, Dickey and Fuller have developed a test known as the augmented Dickey-Fuller (ADF) test.

This test is conducted by "augmenting" the preceding equation by adding the lagged values of the dependent variable $\Delta \mathrm{Y}_{t}$. The ADF test here consists of estimating if the error term $e_{t}$ is auto correlated, one modifies (4) as follows:

$$
\Delta Y_{t}=\beta_{1}+\beta_{2}+\delta Y_{t-1}+\alpha \sum_{i=1}^{m} \Delta Y_{t-i}+\varepsilon_{t}
$$

where $\varepsilon_{\mathrm{t}}$ is a pure white noise error term and where, $\Delta Y_{t-1}=\left(Y_{t-1}-Y_{t-2}\right), \Delta Y_{t-2}=\left(Y_{t-2}-Y_{t-3}\right)$ etc., that is, one uses lagged difference terms. The number of lagged difference terms to include is often determined empirically, the idea being to include enough terms so that the error term in (4) is serially uncorrelated. The null hypothesis is still that $\delta=0$ or $\rho=1$, that is, a unit root exists in Y (i.e., $\mathrm{Y}$ is non-stationary). 
To test the market integration, the following co-integration regression was run for each pair of price series:

$$
Y_{i t}=\alpha_{0}+\alpha_{1} Y_{j t}+\varepsilon_{t}
$$

Where, $Y_{i}$ and $Y_{j}$ are price series of a specific commodity in two markets $i$ and $j$, and $\varepsilon_{t}$ is the residual term assumed to be distributed identically and independently. The test of market integration is straightforward if $\mathrm{Y}_{i}$ and $\mathrm{Y}_{j}$ are stationary variables but if the price series proved as non-stationary then we have to done another test (Engle-Granger test).

Testing whether the variables are co-integrated is merely another unit root test on the residual in equation (5).

However, since the $Y_{i}$ and $Y_{j}$ are individually non-stationary, there is the possibility that the regression is spurious. The DF and ADF tests in the present context are known as Engle-Granger (EG) test whose critical values was provided by Engle-Granger. The test involved regression the first-difference of the residual lagged level and lagged dependent variables (Engle-Granger test) is as follows:

For Engle-Granger (EG) test,

$$
\Delta \varepsilon_{t}=\beta \varepsilon_{t-1}
$$

If the computed value of ' $t$ ' of regression coefficient $\beta$ is higher (in absolute term) than tabulated value, our conclusion is that the residuals from the regression are I (0), that is they are stationary and the regression is not spurious even though individually two variables are non-stationary.

\section{Results and Discussion}

\section{Buying and selling}

An efficient marketing system is essential for earning fair profit for the fish farmers and traders. Marketing functions may be defined as major specialized activities performed in accomplishing the marketing process of concentration, equalization and dispersion [7]. The activities involved in the transfer of goods are completed through buying and selling functions. Aratdars do the functions of negotiation between buyers and sellers of fish and help them at their own business premises on receipt of commission. They do not take the ownership of the products. Rohu farmers sell $85 \%$ of their fish to paiker through aratdar, $15 \%$ to paiker directly and the final $4 \%$ to retailer. Paikers sell $74 \%$ of their fishes to retailers and $26 \%$ to retailers through aratdars. Retailers sell the entire fish to ultimate consumers. Paiker of Rohu purchases $88 \%$ from farmers through aratdar and $12 \%$ directly from farmers. Retailer purchases $87 \%$ from farmers through aratdar and $13 \%$ from farmers. Consumer purchases $100 \%$ of rohu from the retailers in the study area (Table 1).

\section{Grading}

Grading is the basic function of sales transactions and is defined as the classification of products according to some standards or measures [7]. Grading is the sorting of different market quality which facilitates exchange by simplifying buying and selling as it makes the sale by showing sample and description possible. It also simplifies the concentration process and makes easier and less costly the movement of goods through the marketing channel. Grading facilitates sale since different sizes of fish have different prices. In Bangladesh, all intermediaries grade fish on the basis of weight (Table 2).

\section{Storage}

The storage facilities help buyers and sellers to reduce the wide fluctuation of prices between peak and lean seasons. The storage function is primarily concerned with making goods available at the desired time and enables traders to receive better prices for their products. Because of high perishability, fish requires extremely specialized storage facilities matching the seasonal demand. Other intermediaries use only ice to transport fishes from one place to another. Surprisingly, no refrigerated vans are used in Bangladesh to transport fish. All intermediaries use ice during marketing, but their ice to fish ratio is not appropriate. So the quality of fish is deteriorated. In retail selling, some retailers use ice.

\section{Transportation}

Transportation is a basic function of making goods available at proper place and it creates place utility. Perishable goods must be moved as early as possible from the producing centre to the consumer centre. So transportation is essential for highly perishable commodities like fish. Adequate and efficient transportation is a cornerstone for the modern marketing system [7]. In the study areas, the fish farmers and intermediaries use various modes of transports such as van, rickshaw, truck, passenger bus, pickup, nasimon (locally made pick-up type van for transporting passengers and goods), head load etc, to transfer product from the producing areas to the consumption centre. Table 3 , show different modes of transport used by the intermediaries to transport fish from one place to another.

\section{Financing}

The financing function is the advancing of money by someone to carry on the business. For effective operation, financing is of crucial importance in the whole marketing system of rohu. The source of finance for the value chain actors in the study areas are shown in Table 4 which show that most of the fish farmers, aratdars, paikers and retailers of rohu, are self-financed. Other sources of finance for farmers are banks, friends and relatives, and dadon. A minor portion of Aratdar's sources of finance are banks and friends and relatives. Paikers

\begin{tabular}{|c|c|c|c|c|c|c|c|c|c|c|}
\hline \multirow[b]{2}{*}{$\begin{array}{l}\text { Value } \\
\text { actor }\end{array}$} & \multirow[b]{2}{*}{ chain } & \multicolumn{4}{|c|}{ Purchase from (\%) } & \multicolumn{5}{|c|}{ Sold to (\%) } \\
\hline & & Farmer & $\begin{array}{l}\text { Farmer } \\
\text { via } \\
\text { aratdar }\end{array}$ & Paiker & Retailer & Paiker & $\begin{array}{l}\text { Paiker } \\
\text { via aratdar }\end{array}$ & Retailer & $\begin{array}{l}\text { Retailer } \\
\text { aratdar }\end{array}$ & ${ }^{\text {via }}$ Consumer \\
\hline Farmer & & - & - & - & - & 15 & 81 & 4 & - & - \\
\hline Aratdar & & \multicolumn{9}{|c|}{ Aratdars negotiate between buyers and sellers of fish and help them at their own business premises on receipt of Aratdari commission. } \\
\hline Paiker & & 12 & 88 & - & - & - & - & 74 & 26 & - \\
\hline Retailer & & 13 & 87 & - & - & - & - & - & & 100 \\
\hline Consumer & & - & - & - & 100 & - & - & - & - & - \\
\hline
\end{tabular}
take loan from banks, NGO and friends and relatives. In addition to

Table 1. Percent of rohu fish transacted by value chain actors 


\begin{tabular}{|l|c|c|}
\hline Species & Size & Weight \\
\hline \multirow{3}{*}{ Rohu fish } & Large & $2.5 \mathrm{~kg}$ above \\
\cline { 2 - 3 } & Medium & $1.0 \mathrm{~kg}$ to $2.5 \mathrm{~kg}$ \\
\cline { 2 - 3 } & Small & Less than $1 \mathrm{~kg}$ \\
\hline
\end{tabular}

Table 2. Grading practices of rohu fish on the basis of size and weight

\begin{tabular}{|c|c|}
\hline $\begin{array}{l}\text { Farmers and } \\
\text { Intermediaries }\end{array}$ & Mode of transport \\
\hline Fish Farmer & $\begin{array}{l}\text { - } \quad \text { Rickshaw/Van: Three wheel non-mechanized } \\
\text { man-driven carrier } \\
\text { - } \quad \text { Nasimon: Locally made mechanized small lorry/ } \\
\text { van }\end{array}$ \\
\hline Paiker & $\begin{array}{l}\text { \# Bus: Passenger bus (Bottom cargo holder) } \\
\begin{array}{l}\text { - } \quad \text { Truck: Cargo carrier (Non-refrigerated) } \\
\text { - Pickup: Small lorry }\end{array}\end{array}$ \\
\hline Retailer & $\begin{array}{l}\text { - } \quad \text { Head load: Container carry on head } \\
\text { - } \quad \text { Rickshaw/Van: Three wheel non-mechanized } \\
\text { carrier } \\
\text { - } \quad \text { Hus: Passenger bus (Bottom cargo holder/roof } \\
\text { - } \quad \text { Truck: Cargo carrier (Non-refrigerated) } \\
\text { - } \quad \text { Nan } \\
\text { - } \quad \text { Pickup: Small lorry }\end{array}$ \\
\hline
\end{tabular}

Table 3. Mode of transport used by farmers and intermediaries for movement of rohu fish

\begin{tabular}{|l|c|c|c|c|}
\hline \multirow{2}{*}{ Sources of finance } & \multicolumn{3}{|c|}{ Market participants (\%) } & \\
\cline { 2 - 5 } & Farmer & Aratdar & Paiker & Retailer \\
\hline Own fund & 86 & 96 & 82 & 76 \\
\hline Bank & 9 & 3 & 11 & 0 \\
\hline NGO & - & 0 & 5 & 16 \\
\hline Friend and relatives & 4 & 1 & 2 & 8 \\
\hline Dadon from Aratdar & 1 & 0 & 0 & 0 \\
\hline Total & 100 & 100 & 100 & 100 \\
\hline
\end{tabular}

Table 4. Sources of finance of rohu fish farmers and intermediaries

the use of their own fund, retailers also borrow from NGOs and friends and relatives [8].

\section{Packaging}

Packaging may be defined as the general group of activities in product planning which involves designing and producing the container or wrapper for a product [9]. Packaging is essential for proper transportation of fish. 'Basket' made of bamboo, rope and polythene is used by farmers, paikers and retailers of major carps, pangas and tilapia fish. Plastic drums are usually used when fish is transported in live form. Currently, 'plastic crate' is commonly used by all types of intermediaries in Bangladesh (Table 5).

\section{Pricing}

In the study areas, all intermediaries are involved in buying and selling of fish. Farmer, aratdar, paiker, and processing plants practice open bargaining, auction and going market prices method for fixing price of their products in varying degree. Cent percent of the retailers follow open bargain for selling their fish to consumers (Table 6).

\section{Characteristics of market participants}

In the chain of fish marketing of the study areas, the product moves from farmers to consumers through market intermediaries such as Fish farmers, aratdar paiker, Faria and retailer.
Fish farmers and fishermen are the first link in the fish marketing channels. The fish Farmers (producers) of rohu fish usually sell their fish to the local aratdar.

The aratdars are at the centre of the entire marketing system and their role goes far beyond what one would normally expect of a commission agent, including financing of suppliers and buyers, and often dealing on their own account [10]. When fish arrives at the wholesale markets, aratdars take the responsibility and control of each sale. They sell the fish through an auctioning system and get a commission of $3 \%$ to $4 \%$ depending on fish species. Most of the time aratdars recruit koyal (person who organizes auction by uttering and offering different prices for buyers for sale). Koyals have a significant role on pricing the fish. Generally, the aratdars are self-financed. They hire necessary salaried persons or labourers depending upon their volume of business.

Paiker or bepari is conceptually same but used interchangeably in different fish marketing system in Bangladesh who transacts large volume of product. Another type of paiker is seen in hilsha marketing system called L/C paiker. They purchase fish from fishermen through aratdar and sell (export) their entire product to overseas market, especially the Indian markets. Some paikers/beparis receive money in advance from the aratdar on condition that they would sell their fish through them.

Faria is another type of intermediary in the marketing system. They purchase a small quantity of fish form distant fishermen far away from the market and carry it to the terminal point and sell it to aratdar or retailer in the study areas.

Retailer the last intermediaries of fish marketing channel, do not have any permanent establishment but they have fixed places in the market centre or are wandering with hari (aluminum pot) on head from door to door. Usually retailers buy fish from aratdar and sell directly to ultimate consumers. Mostly they purchase fish on cash. Sometimes they also purchase on credit for short term periods. If the size of fish is too large then buyers want the fish to cut into pieces as cutters have sufficient instruments to cut the large fish. Retailers may cut the whole fish for consumers or uses the services of cutters to remove scales and cut into pieces. Depending on the convenience, extra money is charged for removing scales or cut into pieces. In spite of being self-financed, the retailers often borrow money from non-institutional sources at the time of need.

\section{Marketing chains}

Marketing chains are the alternative routes of product flows from producers to consumers [7]. Value chain may be long or short for a particular commodity depending on the qualities of products, size and nature of consumers and producers and the prevailing social and physical environment (Figure 1). Dominant supply chains of rohu in the study areas are shown below:

Value chain - I Fish Farmer $\rightarrow$ AratdarPaiker $\rightarrow$ Retailer Consumer $\rightarrow$

Value chain - II Fish Farmer $\rightarrow$ Paiker $\rightarrow$ Retailer Consumer

Value chain - III Fish Farmer $\rightarrow$ Faria $\rightarrow$ Consume

Value chain - IV Fish Farmer $\rightarrow$ Village market Consumer

Two major value chains are identified for rohu fish in Mymensingh district. These are: 
Citation: Janifa UA, Omar Mdl, Sabur SA, Moniruzzaman M, Haque MdS (2014) Analysis of Marketing Function, Marketing Efficiency and Spatial Co-Integration of Rohu (Labeo Rohita) Fish in Some Selected Areas of Bangladesh. J Bus Fin Aff 3: 123 doi:10.4172/2167-0234.1000123

Page 5 of 9

Value chain - I Fish Farmer $\rightarrow$ AratdarPaiker $\rightarrow$ Retailer Consumer $\rightarrow$

Value chain - II Fish Farmer $\rightarrow$ PaikerRetailer $\rightarrow$ Consumer

\section{Value addition costs by different actors}

The cost incurred to transport the product from producers to consumers is ordinarily known as marketing cost. In other words, the cost of marketing represents the cost of performing various marketing functions [7]. Marketing costs are incurred when commodities are shipped from the farm to the final market. Total marketing cost of fish includes all costs incurred by different intermediaries like inter district paikers, local paikers, aratdars, retailers and farmers who perform some marketing functions in the study areas. Products get value added during their movement across items. Share of transportation cost is the highest (40.54\%) followed by aratdar's commission (26.92\%), icing $(8.23 \%)$, wages and salaries $(4.81 \%)$ and tips \& donations $(4.32 \%)$ for rohu marketing (Table 7). Total value added cost per maund is Taka 953.13 from production point to consumption point. Amongst them, Paiker's value added cost is the highest while aratdar's value added cost is the lowest. Aratdars negotiate between buyers and sellers of fish and assist them in buying and selling at their own business premises on receipt of commission (Figure 2).

\section{Marketing margin}

A marketing margin is the percentage of the final weighted average selling Price taken by each stage of the marketing chain. The

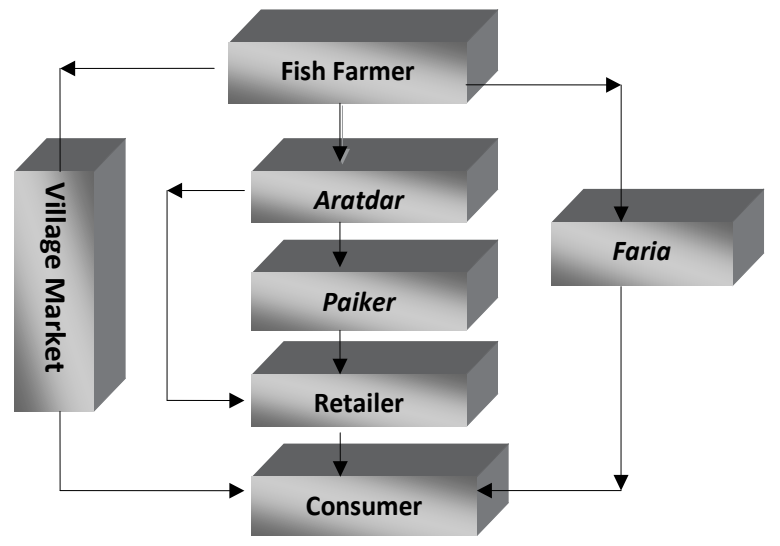

Figure 1. Value chains of rohu fish in Mymensingh district.

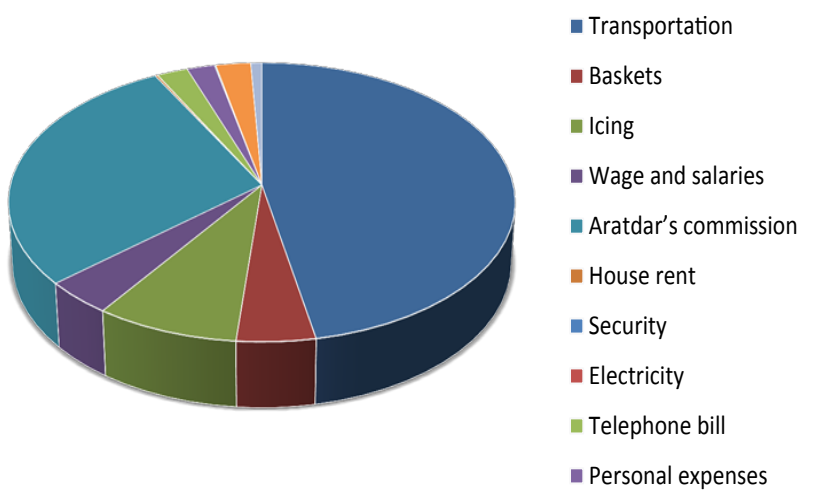

Figure 2. Total marketing cost involved in rohu fish marketing (Taka per maund) margin must cover the costs involved in transferring produce from one stage to the next and provide a reasonable return to those doing the marketing activities [11]. It is also termed as Price spread as it represents the difference between the buying and selling Price. Total marketing margin is the difference between the Price received by the fish Farmers and the Price paid by the final consumers. Marketing margins of fish are calculated separately for different intermediaries. Gross marketing margin of each type of intermediaries is calculated by deducting the purchase Price of fish from their sale Prices while net margin or profit component is calculated by deducting the marketing cost from gross marketing margins. Average net marketing margins of all intermediaries for rohu fish are presented in Table 3. Farmer average marketing cost is Taka 135.00 per maund for all fishes. Amongst all intermediaries, profit of retailers is the highest of Taka 624.29 per maund of fish. Profit of intermediaries varies due to variation in their costs; purchase Price and sales Price (Table 8).

\section{Marketing efficiency}

Marketing efficiency is essential for measuring the degree of marketing performance. On the basis of three methods for measuring marketing efficiency, chain 2 is more efficient (Table 9). In chain 2 the consumer paid lower price per maund rohu compared to chain 1.though in practice chain 1 is mainly used for selling rohu fish in the study area: Considering two value chain on the basis of product flow it was found that value chain-1 is more efficient than value chain- 2 . Consumer paid lower price in value chain-1 compared to value chain-2.

\section{Distribution of value addition cost and net profit}

Table 10 shows the percentages of total value addition cost and total net profit by different intermediaries for different fish marketing system in Bangladesh. For rohu fish, major cost is borne by paikers $32.03 \%$ of total cost) and major net profit is earned by retailers (51.98\% of total net profit). Forrohu, major cost is borne by the inter district beparis, paikers and fishermen but major net profit is earned by retailers and processing plant owners. Farmers, in rohu marketing, bear the major marketing cost ( $23.70 \%$ of total cost) because they have to pay aratdar's commission which ultimately increases their marketing cost.

\section{Market integration of rohu}

To test the stationary of the data, the ADF (Augmented DickeyFuller) test with 13 lags of rohu Prices for Dhaka, Chittagong, Khulna, Sherpur, Comilla, Bogra, Rangpur, Rajshahi, Mymensingh, Sylhet, Gazipur and Noakhali were performed over 2000 to 2012 period and the estimated tau $(\tau)$ statistics and P values in their level and first difference are presented in Table 11. Real Price data were used and data were transformed into natural log. Real Price was calculated by multiplying nominal Price with the corresponding consumer price index (CPI) and dividing by the last CPI of the series. The tau $(\tau)$ statistics which were compared with $\mathrm{p}$ values indicate that all the rohu. Price series data were non-stationary at level. This set of regression was run once more after differencing all the markets. The tau $(\tau)$ statistics on the lagged first-difference terms are significantly negative indication that the series are stationary after first differencing. The study revealed that the rohu. Prices are stationary after differencing once that is they are all (11) processes.

\section{Co-integration regression test results for rohu price in Bangladesh}

To examine whether bivariate co-integration exists between 


\begin{tabular}{|l|c|c|c|}
\hline $\begin{array}{l}\text { Packaging } \\
\text { practices }\end{array}$ & Using materials & Capacity & Used by \\
\hline Basket & $\begin{array}{c}\text { Bamboo, Rope and } \\
\text { Polythene }\end{array}$ & $\begin{array}{l}40 \mathrm{~kg} \\
20 \mathrm{~kg}\end{array}$ & Farmer, Paiker and Retailer \\
\hline Drum & Plastic & $\begin{array}{l}40 \mathrm{~kg} \\
20 \mathrm{~kg}\end{array}$ & Farmer, Paiker and Retailer \\
\hline
\end{tabular}

Table 5. Packaging practices of rohu fish marketing in Bangladesh

\begin{tabular}{|l|c|c|c|c|c|}
\hline Pricing methods & Farmer & Aratdar & Paiker & Retailer & Bepari \\
\hline Auction & 60 & 99 & 37 & 0 & 0 \\
\hline Based on going market prices & 29 & 0 & 30 & 0 & 70 \\
\hline Prefixed prices & 0 & 0 & 0 & 0 & 100 \\
\hline Cost-plus method & 0 & 0 & 0 & 0 & 0 \\
\hline
\end{tabular}

Table 6. Pricing methods followed in selling of rohu fishes in Bangladesh

\begin{tabular}{|l|c|c|c|c|c|}
\hline Cost items & Farmer & Aratdar & Paiker & Retailer & Total \\
\hline Transportation & 39.6 & - & 276.49 & 70.35 & $386.44(40.54)$ \\
\hline Baskets & - & 1.66 & 26.38 & 15.07 & $43.11(4.52)$ \\
\hline Icing & - & - & 48.15 & 29.31 & $77.46(8.13)$ \\
\hline $\begin{array}{l}\text { Wage and } \\
\text { salaries }\end{array}$ & - & 22.75 & 23.23 & - & $45.98(4.82)$ \\
\hline $\begin{array}{l}\text { Aratdar's } \\
\text { commission }\end{array}$ & 88.08 & - & 168.55 & - & $256.63(26.92)$ \\
\hline House rent & - & 5.37 & 1.01 & 19.84 & $26.22(2.75)$ \\
\hline Security & - & 0.10 & 0 & 1.89 & $1.99(0.21)$ \\
\hline Electricity & - & 0.30 & 0.14 & 7.20 & $7.64(0.80)$ \\
\hline Telephone bill & 3.85 & 3.26 & 13.07 & 16.10 & $36.28(3.81)$ \\
\hline $\begin{array}{l}\text { Personal } \\
\text { expenses }\end{array}$ & 2.22 & 6.52 & 11.76 & 20.69 & $41.19(4.32)$ \\
\hline Tips and donation & 4 & 0.70 & 0.52 & 1.02 & $6.24(0.65)$ \\
\hline Wastage & - & - & 14.74 & - & $14.74(1.55)$ \\
\hline Others & - & 0.26 & 4.71 & 4.25 & $9.22(0.97)$ \\
\hline Total & 137.75 & 40.92 & 588.75 & 185.71 & 953.13 \\
\hline
\end{tabular}

Table 7. Total marketing cost of different intermediaries involved in rohu fish marketing (Taka per maund)

different Prices of rohu market, Dhaka wholesale market was considered as reference market, Dhaka is a capital market and the largest city and it would appeared to be the dominant influences on inter districts rohu markets in Bangladesh. The reference market is a dominant market serving as a hub in a sort of "radial market structure" where different feeder (local) markets are at the rim. The reference market dominates the Price formation in the feeder markets. Every individual feeder market was affected by the reference market Price, though it alone cannot affect the reference markets Price.

Normally, the reference markets has a high turnover so that supply and demand shocks originating in the individual feeder markets are absorbed without creating much effect on the Price prevailing in the reference markets [12]. As there will be different combinations of the given 12 whole sale rohu Price markets, all combinations in a systems of bivariate relationships. The Engle-Granger (EG) and Augmented Engle-Granger (AEG) tests of residual equation confirm the stationary of the residual series [13]. Thus ADF results of unit root equation indicate that the real rohu Price series are I (1), while Engle-Granger (EG) and Augmented Engle-Granger (AEG) results of residual equation indicate that the residual series (which are linear combination of above rohu real Price series) are I(0). Thus above fact that the Price series being I ( 1 ) and their linear combination being I (0) point out that the series are co integrated without any exception. According to the Engle-Granger (EG) and Augmented Engle and Granger (AEG) test rohu markets of Bangladesh are statistically significance at $1 \%$ level
(Table 12). An important finding of the study is that Dhaka market is significantly integrated to all regional markets of rohu markets in Bangladesh due to having the facility of information technology, which closely connected the markets to each other. This study strongly supports marketing efficiency in the selected rohu markets. Price move in the unison in all the markets together. Central Price policy making will be effective in these markets.

\section{Strong forms of market integration}

For testing strong form of rohu markets integration, the null hypotheses were applied to find rohu market integration against alternate hypotheses where rohu markets might not be integrated. The result of strong form of market integration in selected rohu markets is given in Table 13. It is seen from Table 13 that strong form of market integration was observed all the rohu markets in Bangladesh due to congenial atmosphere existed in these markets. This empirical finding strongly supports marketing efficiency in the markets. Price move in the unison in all the markets together. Central Price policy would be effective for these markets. For the estimation of strong form of market Integration we used the following restriction.

To calculate pair wise regression of the selected 12 domestic rohu markets prices, the time period was considered from January 2000 to December 2012 and the results are presented in Table 14. Monthly wholesale market price and Log linear model used for the study. The coefficient of Log linear model indicates the elasticity of prices. The entire coefficients are significant at $1 \%$ level. If price of Chittagong market increases 1 per cent then the price of Dhaka market increase 0.66 per cent and vice versa. And if the price of Comilla market increases 1 per cent then the price of Dhaka market increases 0.51 per cent and vice versa. Interpretations of all other coefficients are similar.

The coefficient of Log linear model indicates the elasticity of prices. The entire coefficients are significant at $1 \%$ level. If price of Chittagong market increases 1 per cent then the price of Dhaka market increase 0.66 per cent and vice versa. And if the price of Comilla market increases 1 per cent then the price of Dhaka market increases 0.51 per cent and vice versa. Interpretations of all other coefficients are similar.

\section{Constraints of fish marketing}

Main constraints of fish marketing are related to infrastructure, plant management and institutional management aspect. From the infrastructural constrains, lack of modern, hygienic fish landing centers; illiteracy, ignorance, lack of awareness and poor socioeconomic condition of the fishers; shortage of adequate ice-plants with sufficient capacity, cold and freezer storage; lack of handling and preservation facilities etc are the most severe. Problems are particularly serious in certain inaccessible area where inadequate transportation and distribution facilities, lack of insulated and refrigerated fish vans, resulting in considerable wastage of ice; lack of electricity present and where open trucks are the main fish carriers. According to the traders, marketing and fish transporting also affected by political disturbances. As a result, fishes tend to damage and the traders sell these at lower price than that required obtaining these, sometimes they even unsuccessful to earn any revenue due to decomposition of this perishable commodity. The consumers have to pay higher price due to the participation of too many intermediaries in the marketing channel, but the actual fishers do not get the perfect price for their products and the lion shares go to the intermediary's pocket

Specific suggestions which are needed to improve marketing system are as follows: 
Citation: Janifa UA, Omar Mdl, Sabur SA, Moniruzzaman M, Haque MdS (2014) Analysis of Marketing Function, Marketing Efficiency and Spatial Co-Integration of Rohu (Labeo Rohita) Fish in Some Selected Areas of Bangladesh. J Bus Fin Aff 3: 123 doi:10.4172/2167-0234.1000123

Page 7 of 9

- Establishment of more ice-plants, cold-storage and preservation facilities,

- Introduction of insulated and refrigerated fish vans and fish carriers to maintain cold-chain during transportation,

- Improvement of existing fish market structure,
- Improvement of fish transport, handling facilities,

- Establishment of modern wholesaling facilities,

- Improvement of sanitation, hygienic condition, drainage, washing facilities and sufficient auction places,

- Introduction of mechanical weighing equipment,

\begin{tabular}{|c|c|c|c|c|}
\hline Intermediaries & Purchase Price & Sale Price & Gross marketing margin & Marketing cost \\
\hline Farmer & - & 3540 & 3540 & 135 \\
\hline Aratdar & - & - & 140 & 3405.25 \\
\hline Paikar & 3890 & 4650 & 760 & 305.31 \\
\hline Retailer & 4650 & 5460 & 810 & 185.71 \\
\hline
\end{tabular}

Table 8. Net marketing margin of different intermediaries for rohu fish marketing (Tk/maund)

\begin{tabular}{|l|c|c|}
\hline \multirow{2}{*}{ Particulars } & Unit & Value chain 1 \\
\cline { 2 - 3 } & & 689.69 \\
\hline 1. Total marketing cost & Tk/Maund & 990.50 \\
\hline 2. Total net margins & Tk/Maund & 370.38 \\
\hline 3. Net price received by farmers & Tk/Maund & 689.09 \\
\hline Marketing efficiency (ME) [3/1+2] & Ratio & $\mathbf{2 . 0 3}$ \\
\hline
\end{tabular}

Table 9. Marketing efficiency of rohu fish in Mymensingh market

\begin{tabular}{|l|c|c|}
\hline Intermediaries & \% of total cost & \% of total profit \\
\hline Farmer & 15.45 & - \\
\hline Aratdar & 4.29 & 4.40 \\
\hline Paikar & 32.04 & 27.69 \\
\hline Retailer & 19.45 & 51.98 \\
\hline
\end{tabular}

Table 10. Percentage distribution of value addition cost and profit by intermediaries and marketing system

\begin{tabular}{|c|c|c|c|c|c|c|c|c|}
\hline \multirow[b]{2}{*}{ Markets } & \multirow{2}{*}{$\begin{array}{c}\text { Level } \\
\mathrm{Y}_{\mathrm{t}-1}\end{array}$} & \multirow[b]{2}{*}{ ADF } & \multirow[b]{2}{*}{$\mathbf{P}$} & \multirow[b]{2}{*}{ Decision } & \multicolumn{2}{|c|}{ First difference } & \multirow[b]{2}{*}{$P$ values } & \multirow[b]{2}{*}{ Decision } \\
\hline & & & & & $\Delta \mathbf{Y}_{\mathrm{t}-1}$ & ADF & & \\
\hline \multirow[t]{2}{*}{ details } & $\ln$ & (T) & values & & In & (T) & & \\
\hline & \multicolumn{2}{|c|}{ Coefficient } & & & \multicolumn{2}{|c|}{ Coefficient } & & \\
\hline Dhaka & -0.072 & -1.89 & 0.12 & Non-stationary & -0.142 & -4.64 & 0.00 & Stationary \\
\hline Chittagong & -0.013 & -1.32 & 0.18 & Non-stationary & -0.032 & -3.36 & 0.00 & Stationary \\
\hline Comilla & -.007 & -0.79 & 0.42 & Non-stationary & -0.44 & -8.02 & 0.00 & Stationary \\
\hline Khulna & -0.08 & -1.37 & 0.17 & Non-stationary & -0.19 & -5.20 & 0.00 & Stationary \\
\hline Sherpur & -0.04 & -0.72 & 0.47 & Non-stationary & -0.23 & -5.89 & 0.00 & Stationary \\
\hline Bogra & -0.009 & -0.94 & 0.34 & Non-stationary & -0.29 & -5.39 & 0.00 & Stationary \\
\hline Rangpur & -0.08 & -1.62 & 0.13 & Non-stationary & -0.20 & -5.18 & 0.00 & Stationary \\
\hline Rajshahi & -0.06 & -2.32 & 0.02 & Non-stationary & -0.13 & -4.06 & 0.00 & Stationary \\
\hline Mymensingh & -0.05 & -1.56 & 0.11 & Non-stationary & -0.24 & -6.67 & 0.00 & Stationary \\
\hline Gazipur & -0.04 & -1.42 & 0.15 & Non-stationary & -0.17 & -5.59 & 0.00 & Stationary \\
\hline Sylhet & -0.06 & -2.40 & 0.01 & Non-stationary & -0.13 & -3.94 & 0.00 & Stationary \\
\hline Noakhali & -0.02 & -0.13 & 0.02 & Non-stationary & -0.04 & -2.92 & 0.00 & Stationary \\
\hline
\end{tabular}

ADF= Augmented Dickey-Fuller,

Table 11. Unit root test for wholesale Price of rohu markets in Bangladesh Test critical values: 


\begin{tabular}{|c|c|c|c|c|c|}
\hline Markets details & $E G\left(\ln U_{t-1}\right)$ & $\begin{array}{c}\mathbf{P} \\
\text { values }\end{array}$ & $\left.\begin{array}{c}\text { AEG } \\
(\text { dellnU } \\
t-1\end{array}\right)$ & $P$ values & Decision \\
\hline Dhaka-Chittagong & -3.46 & 0.00 & -3.41 & 0.00 & Co-integrated \\
\hline Dhaka-Comilla & -3.39 & 0.00 & -3.29 & 0.00 & Co-integrated \\
\hline Dhaka-Khulna & -9.10 & 0.00 & -7.24 & 0.00 & Co-integrated \\
\hline Dhaka-Sherpur & -3.88 & 0.00 & -3.65 & 0.00 & Co-integrated \\
\hline Dhaka-Bogra & -3.31 & 0.00 & -3.40 & 0.00 & Co-integrated \\
\hline Dhaka-Rangpur & -7.97 & 0.00 & -6.02 & 0.00 & Co-integrated \\
\hline Dhaka-Rajshahi & -3.76 & 0.00 & -3.62 & 0.00 & Co-integrated \\
\hline Dhaka- Mymensingh & -3.32 & 0.00 & -3.39 & 0.00 & Co-integrated \\
\hline Dhaka- Sylhet & -4.35 & 0.00 & -4.18 & 0.00 & Co-integrated \\
\hline Dhaka-Gazipur & -3.45 & 0.00 & -3.35 & 0.00 & Co-integrated \\
\hline Dhaka-Noakhali & -3.32 & 0.00 & -3.39 & 0.00 & Co-integrated \\
\hline
\end{tabular}

Table 12. Co-integration regression test results for rohu fish price in Bangladesh (Price)

\begin{tabular}{|c|c|c|c|c|c|c|}
\hline \multirow{2}{*}{$\begin{array}{l}\text { Dependent variable } \\
\text { In } \Delta \mathbf{Y}_{\mathbf{t}}\end{array}$} & \multirow{2}{*}{$\begin{array}{l}\text { Independent } \\
\text { variable In }\left(\Delta X_{t}\right)\end{array}$} & \multicolumn{4}{|c|}{ When if $\beta=1$ Than: $\Delta Y_{t}-\Delta X_{t}=\alpha+\partial e_{t-1}+\mu_{t}$} & \multirow{2}{*}{$\begin{array}{c}t \text {-value for } \\
\quad \alpha=0\end{array}$} \\
\hline & & $\begin{array}{c}\text { Coefficient } \\
e_{t-1}\end{array}$ & $\begin{array}{l}\text { Standard } \\
\text { Error }\end{array}$ & $\begin{array}{l}\text { t-value } \\
\beta=1 \text { for }\end{array}$ & $P$ values & \\
\hline Dhaka & Chittagong & $-0.90^{\star *}$ & 0.11 & -8.03 & 0.00 & $-8.06^{\star *}$ \\
\hline Dhaka & Comilla & $-0.09^{* *}$ & 0.04 & -2.09 & $0.03^{*}$ & $2.10^{*}$ \\
\hline Dhaka & Khulna & $-1.31^{\star *}$ & 0.11 & -11.00 & 0.00 & $-11.03^{\star *}$ \\
\hline Dhaka & Sherpur & $0.20^{\star *}$ & 0.06 & 2.98 & 0.00 & $2.99^{\star *}$ \\
\hline Dhaka & Bogra & $-0.85^{\star *}$ & 0.15 & -5.67 & 0.00 & $-5.69^{* *}$ \\
\hline Dhaka & Rangpur & -0.10 & 0.21 & -0.47 & 0.63 & -0.47 \\
\hline Dhaka & Rajshahi & $-1.95^{\star *}$ & 0.12 & -15.92 & 0.00 & $-15.98^{\star \star}$ \\
\hline Dhaka & Mymensingh & $-0.59^{* *}$ & 0.16 & -3.58 & 0.00 & $-3.59^{* *}$ \\
\hline Dhaka & Gazipur & 0.82 & 0.10 & 7.77 & 0.00 & $7.80^{\star *}$ \\
\hline Dhaka & Sylhet & -0.25 & 0.47 & -0.54 & 0.58 & -0.55 \\
\hline Dhaka & Noakhali & -0.07 & 0.04 & 1.67 & 0.09 & 1.68 \\
\hline Dhaka & Chittagong & $-0.48^{* *}$ & 0.10 & -4.52 & 0.00 & $-4.53^{* *}$ \\
\hline
\end{tabular}

Table 13. Testing strong form of integration $(\beta=1, \alpha=0)$ in selected rohu markets in Bangladesh $\left(\Delta \mathrm{Y}_{\mathrm{t}}=\alpha+\beta \Delta \mathrm{X}_{\mathrm{t}}+\partial \mathrm{e}_{\mathrm{t}-1}+\mu_{\mathrm{t}}\right)$

- Proper electric supply,

- Increasing fish supply through improved culture practice,

- Proper attention should be paid to the personal hygiene,

- A study on socio-economic development, credit system,

- Financial and technical assistance,

- Training of manpower,

- An independent act or ordinance for fish landing and marketing.

\section{Conclusion}

The findings of this study indicated that the marketing of rohu is a profitable business. Thus, the selected rohu markets in Bangladesh are shown to be integrated. This is mainly attributed to close proxy, good communication facilities especially development of cell phone technology and good infrastructure availabilities among the market centers in Bangladesh. It also suggests that there is wide scope for the development of rohu farming and trading in this country. In this study the profit of retailer was higher than that of other intermediaries. Though fish marketing in Bangladesh is beset with a number of problems, there have been a number of positive changes that are expected to improve fish marketing environment in the country. These positive drivers includes, i) the shift from subsistence to commercial fish farming, ii) emergence of super-markets, and iii) a changing social attitude towards fish marketing, as it is less considered as a dishonorable 
Citation: Janifa UA, Omar Mdl, Sabur SA, Moniruzzaman M, Haque MdS (2014) Analysis of Marketing Function, Marketing Efficiency and Spatial Co-Integration of Rohu (Labeo Rohita) Fish in Some Selected Areas of Bangladesh. J Bus Fin Aff 3: 123 doi:10.4172/2167-0234.1000123

Page 9 of 9

\begin{tabular}{|c|c|c|c|c|c|}
\hline $\begin{array}{l}\text { Dependent } \\
\text { markets }\end{array}$ & Constant & $P$ values & $\begin{array}{l}\text { Independent markets } \\
\text { (Coefficients) }\end{array}$ & $P$ values & $\mathbf{R}^{2}$ \\
\hline $\ln Y_{t} \quad=$ & $\alpha$ & & $+\beta \ln X_{t}$ & & \\
\hline \multirow[t]{2}{*}{ In Dhaka } & $3.69^{* *}$ & 0.001 & +0.65** InChittagong & 0.00 & 0.39 \\
\hline & $(0.79)$ & & $(0.10)$ & & \\
\hline \multirow[t]{2}{*}{ In Dhaka } & $4.83^{* *}$ & 0.00 & $+0.53^{\star *} \operatorname{InComilla}$ & 0.00 & 0.35 \\
\hline & $(.83)$ & & $(0.10)$ & & \\
\hline \multirow[t]{2}{*}{ In Dhaka } & $1.83^{\star *}$ & 0.00 & $+0.87^{\star *}$ InKhulna & 0.00 & 0.92 \\
\hline & $(0.21)$ & & $(0.02)$ & & \\
\hline \multirow{2}{*}{ In Dhaka } & $4.63^{* *}$ & 0.00 & $+0.51^{* *} \ln$ Sherpur & 0.00 & 0.62 \\
\hline & $(0.43)$ & & $(0.05)$ & & \\
\hline \multirow[t]{2}{*}{ In Dhaka } & $5.26^{\star *}$ & 0.00 & $+0.48^{* *} \ln B o g r a$ & 0.00 & 0.31 \\
\hline & $(1.02)$ & & $(0.12)$ & & \\
\hline \multirow[t]{2}{*}{ In Dhaka } & $2.44^{* *}$ & 0.00 & $+0.82^{* *}$ In Rangpur & 0.00 & 0.87 \\
\hline & $(0.22)$ & & $(0.02)$ & & \\
\hline \multirow[t]{2}{*}{ In Dhaka } & $4.27^{\star *}$ & 0.00 & $+0.59^{\star *}$ In Rajshahi & 0.00 & 0.59 \\
\hline & $(0.50)$ & & $(0.06)$ & & \\
\hline \multirow[t]{2}{*}{ In Dhaka } & $5.82^{\star *}$ & 0.00 & $+0.39^{* *} \ln$ Mymensingh & 0.00 & 0.34 \\
\hline & $(0.76)$ & & $(0.09)$ & & \\
\hline \multirow[t]{2}{*}{ In Dhaka } & $5.03^{\star *}$ & 0.00 & $+0.51^{* *} \ln$ Gazipur & 0.00 & 0.30 \\
\hline & $(0.74)$ & & $(0.09)$ & & \\
\hline \multirow[t]{2}{*}{ In Dhaka } & $2.12^{\star *}$ & 0.00 & +0.81 ln Sylhet & 0.00 & 0.64 \\
\hline & $(0.42)$ & & $(0.05)$ & & \\
\hline \multirow[t]{2}{*}{ In Dhaka } & $4.60^{\star \star}$ & 0.00 & $+0.57^{* *}$ In Noakhali & 0.00 & 0.38 \\
\hline & $(0.83)$ & & $(0.10)$ & & \\
\hline
\end{tabular}

Table 14. Pair wise regression analysis in the selecting domestic rohu markets

job as it was in the past. But the government in Bangladesh needs to ensure that the proper infrastructure and necessary social capital are available for effective participation of all the market intermediaries of the seafood value chain. For better fish marketing, side by side with the private sector, government should also play active role in providing physical facilities like refrigerated storage, refrigerated vans, good market places with related facilities like water, ice, electricity, drainage facilities and sitting arrangements etc. The development of good road and transport networks can reduce superfluous involvement of intermediaries, which could be beneficial for both the fishers/farmers and consumers. Assembling centres with refrigerated storage facilities may be developed so that the perishability of fish is checked, which would enable the assembling centres to make bulk sell/transfer to the next destination. This could reduce post harvest loss and provide better price for the fishers/farmers.

\section{References}

1. Department of DOF (Department of Fisheries). 1999. Annual Report, Department of Fisheries, Dhaka, Bangladesh.

2. Ahmed M, Rab MA, Bimbao MAP (1993) Household socio-economic resource use and marketing in two thanas of Bangladesh. ICLARM Technical Report 04, p. 34.
3. ADB (2005) An evaluation of small-scale freshwater rural aquaculture development for poverty reduction. Operations Evaluation Department, Asian Development Bank, Manila, Philippines.

4. DAM (Department of Agricultural Marketing), (1998-2005). Wholesale price of Agricultural and Animal Products in Bangladesh.

5. Acharya SS, Agarwal NL (1999) "Agricultural Marketing in India", $3^{\text {rd }}$ Edition, Oxford and IBH Publishing Co. Pvt. Ltd., New Delhi.

6. Gujarati DN (2003) Basic Econometrics, Fourth Edition, Tata McGraw-Hill Edition, India.

7. Kohls RL, Uhl JN (2005) Marketing of agricultural products. (9thedn). Macmillan publishing co., Inc., New York.

8. Bangladesh Bank, 2011. Annual Report of Central Bank of Bangladesh 20092013, Accessed date: 22.03.2011.

9. William J Stanton, Michael J Etzel (1991) Fundamentals of Marketing (Paperback).

10. Coulter R, Disney M (1987) A Handbook for Value Chain Research, Internationa Development research Center (IDRC), Canada.

11. Crawford IM (1997) Agricultural and food marketing management. Food and Agricultural Organization of the United Nations, Rome, pp.261-262.

12. Ravallion (1986) Testing Market Integration. American Journal of agricultural Economics, February.

13. Engle RF, Granger CWJ (1987) "Co-integration and Error Correction: Representation, Estimation and Testing". Econometrica 55: 251-276. 